Torpkommissionens betänkande

Author(s): Nils Wohlin

Source: Ekonomisk Tidskrift, Årg. 13, häft 10 (1911), pp. 359-379

Published by: Wiley on behalf of The Scandinavian Journal of Economics

Stable URL: http://www.jstor.org/stable/3437720

Accessed: 25-06-2016 04:41 UTC

Your use of the JSTOR archive indicates your acceptance of the Terms \& Conditions of Use, available at

http://about.jstor.org/terms

JSTOR is a not-for-profit service that helps scholars, researchers, and students discover, use, and build upon a wide range of content in a trusted digital archive. We use information technology and tools to increase productivity and facilitate new forms of scholarship. For more information about JSTOR, please contact support@jstor.org.

Wiley, The Scandinavian Journal of Economics are collaborating with JSTOR to digitize, preserve and extend access to Ekonomisk Tidskrift 


\section{Torpkommissionens betänkande.}

Genıäle af Nils Wohlin.

Uti två nästföregående häften af denna tidskrift har docenten E. Sommarin publicerat en artikel på ej mindre än ett sextiotal sidor, innehållande sanmärkningar och reflexioner t till det af tillkallade sakkunnige den 6 maj d. å. afgifna betänkandet angående torparklassens tillbakagång. Detta betänkande ligger för närvarande på remiss till myndigheter och jordbrukarekorporationer och blifver härvid utan tvifvel föremål för allsidig granskning och sannolikt äfven för kritik och anmärkningar, hvartill ämnets art naturligen föranleder. I likhet med andra kommittéer, som upplösas efter afslutadt arbete, hafva de sakkunnige icke tillfälle att bemöta dessa anmärkningar, än mindre sådana som härleda från personer ur allmänheten. För egen del finner jag mig emellertid i detta fall böra aflämna ett genmäle, icke för att med den ärade granskaren diskutera torparfrågan, hvartill hans reflexioner knappast inbjuda, men för att för tidskriftens läsare påvisa beskaffenheten och värdet af de anmärkningar, han riktat mot kommissionsutlåtandet. Det faller af sig själft, att jag icke svarar å de åtskilda sakkunniges vägnar, utan endast såsom en, hvilken på sin tid tog någon del i deras arbete.

Artikelförfattaren börjar med en granskning af betänkandets bilagor och riktar till en början åtskilliga anmärkningar emot de bland dessa ingående statistiska tabellerna. Dessa anmärkningar gå $\mathrm{i}$ hufvudsak ut därpå, att ingen bestämd gräns dragits mellan å ena sidan sådana torp, som vid den statistiska utredningen medtagits, och å andra sidan sådana backstugor och lägenheter, hvilka därvid uteslutits, till följd hvaraf siffrorna i åtskilliga fall äro bristfälliga; att den statistiska utredningen icke upplyser om medelvärdet af torpprestationerna pr tunnland, utan blott om medelvärdet af samma prestationer för torp inom olika storlekskategorier; att siffermässiga uppgifter icke insamlats om värdet af

Ekonomisk Tidskrift. I9II. Häft. Io. 
de särskilda förmåner, som torparna i regel åtnjuta utöfver brukningsrätten till torpen; att uppgifter om de olika tidpunkterna för öfvergången från dagsverksskyldighet till penningearrende icke åstadkommits; slutligen att ingen statistik åvägabragts öfver naturen $\mathrm{m}$. m. af de jordegendomar, under hvilka torpen lyda.

I afseende å dessa punkter må anmärkas följande. Ehuru för motiveringen till kommissionens afgifna lagförslag och öfriga framställningar icke nödvändig, ansågs dock en statistisk utredning om torparklassens utveckling efter år $1900 \mathrm{~m}$. fl. förhållanden önskvärd. I skrifvelse till chefen för jordbruksdepartementet anhöllo de sakkunnige om frågans hänskjutande till statistiska centralbyrån, hvilken i till departementschefen aflåten svarsskrifvelse, med hänvisning bl. a. till de stora svårigheterna vid en dylik utredning, förklarade sig icke vara i tillfälle att verkställa densamma. Kommissionen beslöt emellertid att taga saken i egna händer och så godt sig göra lät åstadkomma hvad som för densamma var angelägnast, nämligen en statistik öfver antalet af under åren 1900-1910 dels igenlagda, dels friköpta torp, antalet af år I9 IO obesatta torp, torpens fördelning i olika storleksgrupper, torpprestationernas storlek samt slutligen det nuvarande antalet af dagsverkstorp och af emot penningearrende upplåna torp.

Den enda utväg, som härvid lämpligen kunde komma $\mathrm{i}$ betraktande, var att verkställa den statistiska utredningen enligt samma metod som användts af statistiska centralbyrån vid dess utredning om jordtorpen af år r 900 , anbefalld $\mathrm{i}$ anledning af ifrågasatt utsträckning af valrätten till riksdagens andra kammare. Därvid hade tillgått sålunda, att häradsskrifvarna fingo i uppdrag att med ledning af mantalslängderna sockenvis uppgöra förteckningar öfver jordtorparnas namn, torpens benämning samt de hemman, hvarå de särskilda torpen voro belägna. Dessa förteckningar öfversändes därefter till kommunalstämmornas ordförande, som hade att införa penningebeloppet af hvarje jordtorpares afgifter till jordägaren, hvarvid prestationer och dagsverken skulle beräknas enligt markegångstaxan eller eljest i orten gängse pris. Kommunalstämmoordförandena samt kronolänsmännen ålåg det dessförutom att, ifall förteckningen å jordtorparna var ofullständig eller $\mathrm{i}$ följd af inträdda förändringar ej längre med verkliga förhållandet öfverensstämmande, däri göra vederbörliga tillägg och 
rättelser. Att blanketterna $\mathrm{i}$ många fall kommunicerades med jordägarna är antagligt, men kunde naturligtvis icke anbefallas.

Den grundsats, enligt hvilken vid denna utredning jordtorpen afgränsades från andra lägenheter, var att såsom jordtorpare skulle anses sådana personer, som hade att till jordägaren erlägga arrende, dagsverken eller andra prestationer. Statistiska centralbyråns redogörelse innehåller utförliga upplysningar om de svårigheter, som vid ett sådant särskiljande måste uppstå, och som trots den tredubbla granskning, förteckningarna underkastades, nödvändigtvis måste leda till vissa brister hos statistiken, $\mathrm{i}$ den mån frågan gällde de minsta torpen. Det oaktadt har den statistiska utredningen ifråga af år 1900 varit den bästa utredning vi i Sverige ägt om jordtorpen, och som vi öfverhufvud kunna räkna på att få, intill dess att omorganisationen af vår jordbruksstatistik blifver genomförd.

I själfva verket förhåller det sig nämligen så, som hvarje med svensk jordbruksstatistik förtrogen person har sig bekant, att det på enquêtevägen är praktiskt omöjligt att verkställa en specificerad statistik öfver de olika slagen af nyttjanderättsupplåtelser på hemmanens ägor, vare sig att man såsom indelningsgrund lägger besittningsrättens beskaffenhet, jordarealen eller beskaffenheten af prestationerna. Mantals- och taxeringslängderna särskilja icke jordtorpen från den växlande mångfalden af backstugor och smärre huslägenheter på ofri grund, äfvensom åtskilliga jordafsöndringar på viss tid och förpantningar. Häradsskrifvaren äger icke kännedom om besittningsvillkoren, jordarealen eller prestationerna. Kommunalstämmoordförandena äga likaledes i regel endast en ofullständig kännedom om dessa förhållanden, och understundom är t $\mathrm{o}: \mathrm{m}$. jordägaren, ja själfva nyttjanderättshafvaren icke på det klara med beskaffenheten af besittningsvillkoren och storleken af jordarealen. Samtliga dessa förhållanden kunna endast på ett fullt tillfredsställande sätt utrönas genom undersökning på stället i hvarje fall, d. v. s. genom omfattande jordbruksstatistiska lokalundersökningar.

Det behöfver knappast påpekas, att det för torpsakkunnige icke kunde vara någon tanke på undersökningar af detta sistnämnda slag. Ett och annat stickprof hade väl kunnat utföras, men sådana hade på grund af förhållandenas vidt skilda karaktär i olika 
delar af landet blifvit utan värde. En organiserad lokalundersökning af rikets jordtorp kan först väntas i framtiden i sammanhang med de allmänna jordbruksstatistiska lokalundersökningar, som ännu äro beroende på statsmakternas pröfning.

För torpkommissionen fanns ingen annan och bättre utväg än att begagna de vid utredningen âf år $\mathrm{I} 900$ använda förteckningarna öfver jordtorpen, afskrifva dessa förteckningar på särskildt tryckta blanketter, å blanketterna införa kolumner för de uppgifter, som det på enquêtevägen fanns någon utsikt att erhålla, och genom länsstyrelserna utsända frågeblanketterna till besvarande af kommunalstämmoordförandena. Ett utsändande af frågeblanketterna till jordägarna, såsom vid undersökningar enligt den representativa metoden, kunde naturligtvis icke komma ifråga. Att hafva låtit häradsskrifvarna uppgöra nya förteckningar hade varit meningslöst, då intet skäl fanns att antaga att dessa förteckningar ifråga om särskiljandet mellan de smärre jordtorpen och backstugorna hade blifvit mera tillfredsställande än de gamla. Ifråga om detta särskiljande måste kommissionens statistik $\mathrm{i}$ hufvudsak blifva behäftad med samma brister som 1909 års af centralbyrån med vida större apparat och långt rikligare medel verkställda utredning. Detta var naturligtvis för kommissionen på förhand klart, men ansågs icke böra föranleda till den statistiska utredningens inhiberande. En synpunkt, som äfven härvid kom i betraktande, var att endast genom begagnande af förteckningarna från år I 900 någon möjlighet fanns att jämföra siffrorna för åren I 900 och I 9 IO och såmedelst vinna upplysning om antalet af under åren 1900-I9 Io igenlagda och friköpta torp. Hade en statistisk utredning verkställts för år I 9 Io med en efter nya grunder dragen gräns mellan torpen och backstugorna, så hade en sådan jämförelse gifvetvis omöjliggjorts. Men denna jämförelse var ett hufvudsyfte med utredningen.

Utan att beakta, att man endast genom lokalundersökningar kan öfvervinna de svårigheter, hvarmed all svensk jordbruksstatistik hitintills måst kämpa, och oaktadt han är underrättad om sättet för verkställandet af torpsakkunniges statistiska utredning, uppradar nu granskaren af denna utredning en mängd punkter, hvaruti han anser densamma icke vara nog fullständig. Att gränsen mellan sådana torp, som medtagits i statistiken, och sådana lägenheter, som uteslutits därur, icke har kunnat dragas efter mera 
enhetliga normer än som skedde år 1900, har ofvan påpekats. Detta är en brist, som de sakkunnige själfva anmärka, men som har varit oundviklig. Huru stor betydelse man bör tillägga denna brist är svårt att afgöra, men framhållas bör, att hr S. åtminstone föga bidrager till sakens belysning. Han finner för en socken $\mathrm{i}$ Kristianstads län, att kommissionens utredning för år 1910 upptager $5^{8}$ torp, medan en efter obekanta grunder verkställd kontrollräkning af kommunalordföranden angifver summan för år I 9 I I till 66 torp och lägenheter på ofri grund. Skillnaden är icke stor och kan förklaras på många sätt. Till en annan uppgift angående ett härad i Malmöhus län fogas ingen upplysning om källan. Att Malmöhus län $\mathrm{i}$ kommissionens statistik ingår med låga torpsiffror, är icke öfverraskande, då tydligt är, att häradsskrifvarna i öfverensstämmelse med $t$. ex. länets hushållningssällskaps uppfattning $^{1}$ icke inräknat daglönareställena bland torpen.

För hvarje praktiskt erfaren statistiker är det vidare klart, att torpsakkunnige gingo till den yttersta gränsen af hvad som genom enquêten kunde inhämtas, då de för hvarje torp begärde uppgift om antalet af dagsverken, storleken af kontant arrende, penningevärdet af öfriga prestationer samt om det förhållandet, till hvilken af sex angifna storleksgrupper torpet $\mathrm{i}$ afseende å inägoarealen hörde. Att hafva begärt uppgift om den exakta inägoarealen af hvarje torp, för att dymedelst kunna beräkna torpprestationernas medelstorlek för torp om I, 2, 3 etc. tunnland, skulle hafva föranledt att $\mathrm{i}$ en mängd fall inga upplysningar alls erhållits. Att begära upplysning om den ofta ganska aflägsna tidpunkt, då öfvergång ägde rum från dagsverksskyldighet till penningearrende, kunde naturligtvis icke komma ifråga i en till kommunalstämmoordförandena utskickad frågeblankett. Därpå hade $\mathrm{i}$ många fall icke ens de nuvarande jordägarna kunnat lämna svar. En specifikation af torpen efter hemmansnaturen och hemmansägarens juridiska beskaffenhet hade fordrat en kollationering med jordeböcker och fastighetsböcker, hvarpå hvarje tanke var utesluten. En statistik slutligen öfver penningevärdet af de särskilda förmåner, hvilka torparna åtnjuta utöfver brukningsrätten till torpen, kunde, hur önsklig den än varit och hur mycken vikt kommissionen än lade vid denna punkt, minst af allt komma i betrak-

1 Torpsakkunniges betänkande sid. 232. 
tande. Granskaren ådagalägger brist på praktisk läggning, då han tror, att kommunalordförandena $i$ det nutida Sverige skulle kunna lämna specificerade sifferuppgifter om värdet af alla de olika förmånerna ifråga för hvarje torp inom sina kommuner. ${ }^{1}$ Enstaka uppgifter hade visserligen vid lokala besök kunnat insamlas, men skulle med hänsyn till förhållandenas olikhet på olika orter hafva varit nästan utan värde.

Frågar man nu hvad som vunnits och icke vunnits genom kommissionens statistiska utredning, så kan sägas följande. Utredningen gifver tillfredsställande siffror öfver antalet af I900I9 10 i de olika delarna af riket igenlagda torp, af under samma tid friköpta torp och af år I9Io obesatta torp. Den gifver en ganska tillfredsställande klassifikation af torpen i sex olika grupper, efter den odlade arealens storlek; en klassifikation, som förut alldeles saknats och som för den verkställda utredningen af torparfrågan varit af betydelse. Den gifver vidare en statistik öfver torpprestationernas, efter samma grunder som vid 1900 års utredning, beräknade värden, i genomsnitt för torpen inom enhvar af de nämnda sex storleksgrupperna. Att dessa medelvärden för torpen inom de minsta grupperna äro mindre vägledande, ligger i sakens natur, men dessa siffror användas icke heller $i$ betänkandets text. Huru de skola läsas, förstår hvar och en som begagnar sitt sunda förstånd. Slutligen gifver utredningen uppgift om i de olika delarna af riket förefintliga torp, för hvilka prestationerna utgå dels enbart med dagsverken, dels med både dagsverken och penningar, dels enbart med penningar. Dessa siftror, som finnas specificerade för torpen inom hvar och en af de olika storleksgrupperna, äro ganska tillfredsställande.

Hvad som icke vunnits och som för betänkandet hade varit af betydelse är hufvudsakligen den af praktiska skäl omöjliggjorda statistiken öfver värdet af torparnas särskilda förmåner. Hade sådana siffror kunnat erhållas, så hade man kunnat subtrahera dem från siffrorna öfver torpprestationernas beräknade värden och därigenom vunnit kännedom om torparrendenas storlek i förhållande till andra arrenden. Detta har nu icke varit möjligt, men å andra sidan bör påpekas, att kommissionen ingenstädes förbisett betydelsen af denna brist hos det statistiska materialet och ingen-

1 Artikeln sid. 255-6. 
städes, där så kommit ifråga, underlåtit att betona densamma. På det ställe, där de nämnda siffrorna öfver torpprestationernas värden i betänkandet komma till användning, framhålles tvärtom på det uttryckligaste denna brist och drages $\mathrm{i}$ följd däraf slutsatserna med den yttersta försiktighet.

De öfriga anmärkta luckorna hos den statistiska utredningen hafva icke för kommittéutredningen förorsakat någon olägenhet. De afgifna förslagen och motiveringen till desamma hafva icke kräft någon specifikation af torpen efter hemmanens natur m. m. och icke heller någon statistik öfver de olika tidpunkterna för öfvergången från dagsverksskyldighet till penningearrende. Endast såtillvida äro granskarens anmärkningar i dessa afseenden befogade, att en särskild statistik öfver kronotorpen hade varit på sin plats. I afseende å denna kategori af torp, kan, i motsats till förhållandet ifråga om andra torp, tillförlitliga upplysningar anskaffas i alla anmärkta punkter. Beträffande denna fråga bör jag emellertid upplysa, att torpkommissionen, som hade för afsikt att i ett senare betänkande särskildt behandla frågan om kronotorpen, år I 910 genom domänstyrelsens förmedling införskaffade material till en ingående statistik öfver dessa. På grund af dåvarande departementschefens bristande intresse för saken blef det dock intet af denna särskilda utredning, och det statistiska materialet ligger ännu obearbetadt.

Jag har dröjt något utförligt vid den $\mathrm{i}$ och för sig mindre betydelsefulla frågan om de statistiska tabellerna, då detta är den punkt, där anmärkningarna skenbart kunna synas hafva mest fog för sig. Ingenting är nämligen lättare än att kritisera statistiska utredningar, i synnerhet på så svåra områden som det ifrågavarande, att påvisa brister hos siffermaterialet och att uppställa allehanda anspråk. Vederhäftigheten hos kritiken röjer sig emellertid icke genom åthäfvor af denna art, utan därigenom att kritikern beaktar de förhållanden, hvarunder utredningen måst verkställas, sätter sig själf i utredarens ställe och allvarligt bedömer hvad som genom den använda metoden praktiskt har kunnat vinnas och hvad som icke har varit möjligt.

Jag går härmed vidare och kan fatta mig kort om de sidor, på hvilka hr Sommarin refererar kommissionens infordrade 
utlåtanden, reseprotokoll $\mathrm{m}$. m. Såsom referat betraktad torde framställningen väcka föga tillfredsställelse hos utlåtandenas författare, uppblandad som den är med allehanda referentens egna, mestadels harmlösa reflexioner. Här och hvar förekommer dock äfven i detta sammanhang ett litet utfall mot kommissionen. Exempelvis förklaras denna "hafva utan kritik anslutit sig till landtarbetsgifvareföreningarnes diskutabla synpunkter» om jordtorpsystemets stora betydelse såsom ett led i statarens öfvergång till småbonde. Ett underligt påstående, då kommissionen, ehuru den på ett ställe $\mathrm{i}$ betänkandet framhåller det element af sanning, som ligger häri, dock i motsats mot landtarbetsgifvareföreningarna kraftigt understryker önskvärdheten af därför lämpade torps förvandling till egna hem, d. v. s. det ifrågavarande mellanledets borttagande. På ett annat ställe förebrås kommissionen att icke under sin resa hafva slagit upp sidan $236 \mathrm{i}$ den gamla kända skriften af von Möller för att finna exempel på huru godsarrendatorer kunna utnyttja sina torpare. På ett tredje ställe insinueras, att kommissionen låtit arbetet under sin resa "gå undan med för stark fart», det vill förmodligen säga att den icke låtit torparbefolkningens uppfattning komma nog till sin rätt. En likaledes obefogad anmärkning, då man tvärtom gjorde sig den största möda att låta denna uppfattning komma till synes och då $\mathrm{i}$ reseprotokollen ej mindre än öfver I 30 torpare från skilda provinser fått sina uttalanden till trycket befordrade. Med undantag af ett par föregående kommittéer har ingen nyare officiell svensk utredning mera än torpkommissionen låtit allmogens egna åsikter komma till heders.

Lämnande dessa och några andra små besynnerliga anmärkningar åsido, öfvergår jag till den andra hufvudanmärkning emot kommissionens utredning, som jag lyckas få fram ur de ganska kaotiska reflexionerna. Denna går ut därpå, att den historiska utredningen varit för knapphändig och att kommissionen icke gett sig in på att »klargöra begreppen» ifråga om de olika slagen af torp och backstugor.

Härvid torde böra anmärkas, hvad referenten måhända haft sig bekant, att den omedelbara anledningen till att torparfrågan år I909 togs upp af statsmakterna var en skrift i ämnet, författad utaf en af de sakkunnige och ingående bland emigrationsutredningens bilagor. ${ }^{1}$ I denna skrift finnes en visserligen

${ }^{1}$ Bil. XI. 
icke på långt när uttömmande, men dock tämligen omfångsrik historisk redogörelse för de olika formerna af nyttjanderättsupplåtelser på hemmanens ägor, för torparklassens numeriska förändringar sedan 1750 och för torparfrågans utveckling under I 800-talet. Intet hade varit lättare än att låta delar af denna framställning inflyta $i$ kommissionsbetänkandet, och kompletterande historiska rechercher kunde väl äfvenledes hafva verkställts. Såsom hvar och en lätt förstår, har kommissionen af siktligen underlåtit detta. Dess uppdrag var att arbeta vidare på den fråga, som upptagits $\mathrm{i}$ den preliminära utredningen, och att utan onödig tidsutdräkt klarlägga hvad statsmakterna kunna göra emot den tillbakagång af torparklassen, som hvarje år fortgår. Mera af historiska utredningar än som var nödvändigt för klargörandet af den nutida situationen skulle fördenskull icke endast hafva varit obehöfligt, men klandervärdt.

Referenten finner emellertid att kommissionen, för att kunna ådagalägga orsakssammanhanget vid torparklassens numeriska tillbakagång $\mathrm{i}$ vår tid, nödvändigtvis bort hafva ’ej blott grundligt statistiskt-historiskt analyserat torparklassen och torpen utan äfven underkastat torpinstitutionen såsom arbetssystem inom jordbruket en ekonomisk och historisk utredning '. Lika intressant en sådan undersökning $\mathrm{i}$ ekonomisk historia vore $\mathrm{i}$ och för sig, lika otillbörlig hade den varit $\mathrm{i}$ det sammanhang, där referenten felaktigt trott den vara nödvändig. Undersökningen ifråga borde enligt referentens mening hafva sträckt sig tillbaka till medeltiden, klargjort dagsverksskyldighetens förekomst på krono-, kyrko- och frälsegods under I500-, I600- och I 700-talen m. m. En uppbygglig tanke. Personer, tillkallade i jordbruksdepartementet år 1909 för att föreslå åtgärder emot den allmänt kända företeelsen, att torparnas antal under de senare decennierna minskats, skulle ligga i kammararkivet och bedrifva omfattande forskningar om dagsverksskyldigheten under I 500 -talet. Detta medan den stora klass af svenska medborgare, uppdraget afsåg, väntade på ett uttryck af statsmakternas intresse för deras nog så tryckta förhållanden.

Låtom oss nu se hvad den i praktiska ting tydligen bortkomne referenten anser skulle hafva vunnits genom sådana forskningar. Jo, den nämnda till medeltiden gående historiska undersökningen sskulle otvifvelaktigt ha gifvit vid handen, att torp- 
systemets väsentliga drag är dagsverksskyldigheten, att torpinstitutionen måste anses faktiskt afskaffad, där dagsverksskyldigheten ej längre i någon form förekommer, att dagsverksskyldighet, knuten till jordupplåtelse, leder sitt historiska ursprung redan från medeltiden» o. s. v. - här följa några spekulationer om dagsverksskyldighetens förekomst under de senare århundradena - samt "att dagsverksskyldigheten under I800-talets senare hälft i stor utsträckning kommit ur bruk äfven vid torpupplåtelser och att den, där den ännu förekommer, reglerats $\mathrm{i}$ inskränkande riktning af den nyare lagstiftningen, särskildt arrendelagen af år 1907» .

För att ådagalägga att torpsystemets väsentliga drag är dagsverksskyldigheten, att denna under senare tid kommit mera ur bruk och reglerats af 1907 års lag o. s. v. skulle alltså torpkommissionen hafva bedrifvit forskningar, begynnande med medeltiden! Jag tillåter mig här ett utropstecken, som jag eljest icke älskar så mycket som hr S. Jag behöfver icke heller dröja längre vid denna punkt, men vill dock rättvisligen erkänna, att de vetenskapliga intentioner, som referenten lägger $\mathrm{i}$ dagen, gifvetvis äro värda erkännande. Resultera dessa intentioner $\mathrm{i}$ en historisk undersökning om dagsverkssystemet i Sverige, skall jag vara den förste att erkänna den vetenskapliga betydelsen af densamma. Dock torde hr S. i sådant fall nödgas väsentligt fördjupa sina jordbrukshistoriska studier, innan han begynner med arkivforskningen. Det lilla stycke, där han skisserar sin utredning, är försedt med en stor apparat af ej mindre än sex noter, ådagaläggande att han läst de allmänt kända böckerna af von Möller och Thulin samt en artikel af en sydsvensk språkprofessor om orden "torp" och "dorf". Frågan om dagsverksskyldighet såsom vederlag för brukningsrätt till jord och detta systems utveckling ända från antikens dagar är dock ett uppmärksammadt kapitel i den europeiska agrarlitteraturen.

Jag läser vidare i referatet öfver kommissionens allmänna betänkande och finner intet anmärkningsvärdt än här och hvar små missuppfattningar hos referenten af satsbyggnaden i kommittétexten, små förbiseenden af att hvad referenten önskat finna framhållet på ett ställe återfinnes $\mathrm{i}$ sitt rätta sammanhang på ett annat o. s. v. ${ }^{1}$

${ }^{1}$ Se t. ex. anmärkningen å sid. 277 , som faller till marken, då man läser kommittéframställningen i sammanhang. 
Jag vill icke belasta en vetenskaplig tidskrifts utrymme med dessa småsaker utan öfvergår till de anmärkningar, som hafva afseende å kommissionens motiv till afstyrkandet af en tvångsaflösningspolitik ifråga om jordtorpen. Fortfarande är det min afsikt, icke att ingå i diskussion med referenten i själfva sakfrågorna, men väl att ytterligare ådagalägga arten af den kritik, han presterar.

Det finnes som bekant en till ytterlighet gående konservativ - för femtio à hundra år sedan liberal - uppfattning, som $\mathrm{i}$ äganderätten ser en öfver alla andra upphöjd idé, som aldrig bör angripas huru än de sociala förhållandena gestalta sig i ett samhälle. Torpkommissionen frambåller, att den icke står på denna extrema ståndpunkt. Grundsatsen, framhåller kommissionen, att expropriationsåtgärden, som riktar sig mot en enskild samhällsborgare, endast kan komma ifråga till förmån för det allmänna, icke till förmån för en annan enskild samhällsmedlem, är visserligen under vanliga förhållanden väl grundad, och dess frångående skulle under sådana förhållanden $i$ väsentlig grad äfventyra äganderättsförhållandena och samhällets lugna utveckling. Detta torde emellertid, fortsätter kommissionen, icke utesluta, att sådana osedvanliga sociala förhållanden kunna råda inom ett samhälle och ett så betydande statsintresse föreligga, att en expropriationslagstiftning till förmån för en viss samhällsklass kan göras befogad och påkallad.

Den, som icke godkänner denna uppfattning, måste ju ogilla t. ex. de stora reduktionerna på I 500- och I600-talen, sbondefrigörelsen" $i$ en mängd europeiska stater under förra delen af $1800-$ talet och den nya engelska småbrukslagstiftningen af år 1907 . Skulle man $\mathrm{i}$ våra dagars Sverige stå på denna ståndpunkt, kunde det gifvetvis icke komma ifråga, att man ens inginge på ett bemötande af de från socialdemokratiskt håll framkastade idéerna om expropriation och tvångsaflösning $\mathrm{m}$. $\mathrm{m}$. för socialpolitiska syften. Uti en utredning af torparfrågan vore det $\mathrm{i}$ så fall verkligen en onödig och opåkallad utvikning från ämnet att ingå på detta spörsmål. Nu hade emellertid torpkommissionen så mycket mindre skäl att intaga denna högdragna ståndpunkt, som motioner med förslag till utredning af frågan om tvångsaflösning utaf bl. a. jordtorp flera gånger varit före $\mathrm{i}$ riksdagen och kommissionen själf $\mathrm{i}$ sitt betänkande ådagalagt, att det $\mathrm{i}$ förhållande till torparnas ekonomiska resurser höga priset å till salu utbjudna torp varit ett anmärk- 
ningsvärdt hinder mot friköpningsrörelsens utveckling och torparbefolkningens bevarande.

Af detta skäl, framhålles i betänkandet, har kommissionen ansett det falla inom ramen för dess uppdrag att taga jämväl nu berörda fråga $\mathrm{i}$ noggrant öfvervägande. I sådant afseende refererar kommissionen de ifrågavarande socialdemokratiska motionernas innehåll och ingår på en ganska utförlig diskussion af de skäl, som kunna anföras för och emot en lagstiftning om tvångsaflösning af jordtorp. Den påpekar, att de af en sådan lagstiftnings förkämpar ofta åberopade parallellerna med bondefrigörelsen $\mathrm{i}$ vissa länder under förra delen af I 8oo-talet, med förhållandena i England o.s. v. icke $\mathrm{i}$ det nutida Sverige lämpligen kunna andragas. Den framhåller vidare, att om emigrationen, som ju kanske utgör den betänkligaste företeelsen $\mathrm{i}$ vårt lands senare historia, verkligen kunde afsevärdt motverkas genom i de nuvarande jordäganderättsförhållandena ingripande åtgärder, sådana åtgärder visserligen, enligt kommissionens mening, skulle kunna tagas under ompröfning. Men då emigrationen $\mathrm{i}$ Sverige finner stark näring äfven inom den själfägande jordbrukarklassen, kan det icke anses påkalladt att med hänvisning till emigrationsföreteelsen ifrågasätta en rubbning af de nuvarande äganderättsförhållandena till den svenska jorden. Kommissionen ingår därefter på flera andra skäl, som bestämdt tala emot en tvångsaflösning af jordtorpen. Sålunda framhållas de skadliga följder för hufvudgårdarna, som skulle uppstå genom en lagstiftning, som i tvångsväg, emot jordägarnas vilja, framdrefve med stora omkostnader förbundna omläggningar af jordegendomarnas drift. Med stöd af kommissionens infordrade uppgifter påvisas, hvilken betydande omsättning som under senare tiderägt rum och äger rum på torpen, huru de gamla torparsläkterna i stor utsträckning försvunnit för yngre torpare, som ingalunda önska att mera än ett visst antal år kvarstanna på torpen, och huru det skulle gifva anledning till godtycklighet och orättvisa och praktiskt sedt inveckla lagstiftningen i olösliga svårigheter, om man skulle försöka att draga en gräns mellan sådana torpinnehafvare, som borde få rätt till inlösen, och sådana, som icke borde medgifvas denna rätt. Det påpekas, att dessa svårigheter ytterligare skulle ökas därigenom, att de gamla torpinnehafvarna ofta utgöras af ålderstigna och orkeslösa personer, ej sällan kvinnor, hvilka antingen 
sakna hemmavarande afkomlingar eller ock endast äga sådana, hos hvilka lust eller förmåga att rätt bruka torpet felas. Kommissionen utvecklar vidare, hvilket uppenbarligen just i detta sammanhang är af betydelse, farorna för torparna själfva af en för stark forcering af friköpningsrörelsen, där nödiga förutsättningar för själfbestånd felas. Slutligen betonas de rubbningar $i$ afseende \& fastighetskrediten med däraf följande skadliga och oberäkneliga följder för det svenska jordbruket, som skulle blifva en följd af en tvångsaflösningslagstiftning af jordtorpen; en sida af frågan, på hvilken kommissionen icke anser sig behöfva närmare ingå, då de betänkligheter, som i detta afseende framställa sig, äro uppenbara och $i$ ögonen fallande. Af dessa olika skäl afstyrkes en lagstiftning af nämnda art.

Hvad kallar nu författaren till de sextiotre sidornas reflexioner denna strängt sakliga framställning? Den är en sutvikning från ämnet, ägnad att tilldraga betänkandet en mindre fördelaktig uppmärksamhet. Detta lilla utfall träffar mera den socialdemokratiska riksdagsgruppens motioner än torpkommissionen och har för öfrigt ingen betydelse. Men vidare: i princip har torpkommissionen intet att invända emot expropriation af torpen, men saf rena opportunitetsskäl afvisas den naturliga konsekvensen af en så radikal princip s. ${ }^{1}$ Därför att torpkommissionen erkänner, att det kan finnas kritiska skeden i folkens historia, då reduktioner kunna vara nödvändiga, har den i princip intet att invända emot en tvångsaflösning af torpen $\mathrm{i}$ våra dagars Sverige, som kommissionen ju principiellt afstyrker. Och då kommissionen på grund af en rad af ekonomiska öfverväganden afstyrker en sådan tvångsaflösning, gör den detta af rena opportunitetsskäl. At en trubbigare tankekraft har väl sällan tillträde gifvits till en vetenskaplig tidskrift. Sedan följa några försök till bemötande af kommissionens anförda skäl emot tvångsafösning. Ingenting vore enklare, skrifver recensenten, än att uppdraga en gräns $\mathrm{i}$ lag mellan sådana torpare, som borde fá lösningsrätt, och sådana, som borde vara uteslutna därifrån. Kommissionens väl motiverade anmärkning om svårigheterna för den praktiska lagstiftningen på denna punkt är rena fraser och kommissionens ordförande, tillika ordförande $\mathrm{i}$ den nyligen afslutade

1 Sid. $302-303$. 
skiftesstadgekommittén och som bekant en af vårt lands främste lagtextförfattare på fastighetsväsendets område, förklaras af den i lagstiftningsvärf förmodligen förfarne docenten Sommarin hafva hvarken kompetens eller auktoritet för uttalanden om lagstiftningssvårigheter. Önskvärdheten af en omläggning af arbetsförhållandena på många svenska jordbruk, som kommissionen själf i sitt utlåtande om stattorpsystemet förordar, tages af hr S. till stöd för uppfattningen, att en genom tvångsaflösning framkallad plötslig och påtvungen omläggning skulle vara hälsosam; en uppfattning, vittnande om frånvaron af den insikt $i$ jordbrukets driftsekonomi, hvaraf recensenten flerstädes berömmer sig. I afseende slutligen å frågan om tvångsaflösningens ogynnsamma inflytande på fastighetskrediten har recensenten samma uppfattning som kommissionen, men förebrår denna att icke till belysning häraf hafva medtagit en del räkneexempel, som kunna höra hemma i elementära seminarieöfningar och bland recensentens reflexioner, men som hade varit onödiga och olämpliga $\mathrm{i}$ ett officiellt betänkande.

I fråga om de framställda anmärkningarna mot kommissionens afgifna lagförslag och öfriga framställningar skall jag söka fatta mig möjligast kort.

Flera af dessa förslag, däribland de viktiga förslagen till vissa bestämmelser, åsyftande att underlätta friköpning af lägenheter och dessas befriande från på dem hvilande andelar af stamfastighetens gäld, underkastar recensenten alls ingen granskning vare sig ifråga om förslagens förutsättningar eller närmare beskaffenhet, utan öfverlämnar detta förståndigt nog åt den juridiska fackkunskapen. ${ }^{1}$ Icke desto mindre kommer han till det resultat, att de böra läggas ad acta. $^{2}$

Det afgifna förslaget till lag om lösningsrätt för innehafvare af vissa på fyrationio år och längre tid afsöndrade lägenheter, hvarom man naturligtvis kan hafva olika meningar, har, såsom kommissionen själf anmärker, icke grundats på en statistisk utredning om antalet af dessa upplåtelser i rikets olika delar. Orsaken härtill framgår af hvad ofvan anförts om kommissionens statistiska utredning, som icke medgaf verkställandet af en sådan statistik. Gifvetvis är detta en brist, men man får naturligtvis förutsätta, att

1 Sid. 322.

2 Samma sida. 
om lagförslaget ifråga, som utgör det första försök $i$ sin art $i$ vårt land, befinnes förtjänt att tagas under fortsatt ompröfning, kungl. maj:t i sammanhang därmed skall införskaffa nämnda statistiska uppgifter. Att vid bedömandet af lagförslaget hänsyn jämväl bör tagas till med fastighetskrediten sammanhängande förhållanden, är gifvet och kan naturligtvis af ingen förbises. Huru emellertid kritiken än må komma att ställa sig till denna lösningslag, skall den utan tvifvel underkänna den anmärkning, som hr S. riktar emot densamma, nämligen att det är en brist hos lagen att icke undantagslöst medgifva lösningsrätt åt alla innehafvare af dylika lägenheter. Endast under vissa omständigheter bör en sådan rätt komma ifråga, på sätt i kommissionens betänkande finnes närmare utfördt. Att tillämpandet af lagens föreskrifter måste öfverlåtas åt vissa utförande myndigheter, hos hvilka en viss kompetens måste förutsättas för detta uppdrag, står i öfverensstämmelse med hvad på andra lagstiftningsområden förekommer. Att lagens tillämpning på grund häraf skulle blifva beroende af tillämparnas subjektiva godtycke, är en anmärkning, som kan riktas mot all möjlig lagstiftning. Beträffande lagförslaget $i$ öfrigt synes granskaren hafva förbisett, att det föreslagna medgifvandet till lösningsrätt är inskränkt till en mycket begränsad grupp bland de lägenhetsinnehafvare, som åsyftas i Östergötlands läns hushållningssällskaps skrifvelse af den 22 mars i9 10.

Torpkommissionens förslag till vissa ändringar i 1907 års arrendelag, åsyftande att beträffande dagsverkstorp och andra un. der hufvudgård lydande lägenheter dels något utvidga jordägarens. skyldigheter ifråga om underhåll af arrendelägenhetens bostads. och ekonomibyggnader, dels tillerkänna arrendatorn en något utvidgad rätt till ersättning för gjorda förbättringar, stå i öfverensstämmelse med. de nyare grundsatser på arrendelagstiftningens område, som kommit till uttryck $\mathrm{i}$ lagen af den 25 juni 1909 om arrende af viss jord å landet inom Dalarna och Norrland. Emot dessa lagförslag, liksom öfver hufvud emot alla ingripanden af lagstiftningen $\mathrm{i}$ förhållandet mellan jordägare och torpare, kan alltid den anmärkningen riktas, att ingripandena ifråga kunna leda till ovilja hos jordägarna emot torpinstitutionen och därmed till torpens indragning, d. v. s. att man genom dylika åtgärder kan mera skada än gagna torpinstitutionen. Torpkommissionen har, såsom af dess betänkande 
framgår, tillmätt denna synpunkt stor betydelse, men icke desto mindre efter noggrann ompröfning ansett sig kunna förorda de små förbättringar i torparklassens rättsliga ställning, som lagförslagen innebära. Här, som på flera andra punkter, är hr S:s referat af kommissionens förslag vilseledande. Uti den allmänna motiveringen anför kommissionen erfarenheter från sin resa och omnämner, att $\mathrm{i}$ några fall gods anträffades, där torpbyggnaderna voro till ytterlighet förfallna. Det synes uppenbart, anföres med hänsyftning på dessa reseerfarenheter, att inga utsikter $\mathrm{i}$ dessa fall förefinnas att för framtiden bevara torpinstitutionen, försåvida icke genomgripande reparationer, i somliga fall ombyggnader af torpens bostads- och ekonomihus, blifva verkställda. ${ }^{1}$ Denna passus griper recensenten ut ur sitt sammanhang och förklarar kommissionens förslag till lagändringar vara afsedda att frambringa sådana ombyggnader å torpen samt ordar om farorna af en "sträng och ökad återbyggnadsskyldighet» för jordägarna. Redan den flyktigaste blick på lagförslaget och dess motivering ger vid handen, att kommissionen icke föreslagit någon återbyggnadsskyldighet, utan endast reparationsskyldighet. Förbisett har recensenten dessutom, att åt bestämmelserna ifråga icke gifvits tvingande natur. ${ }^{2}$ Kommissionens förslag afser torpens såväl bostads- som ekonomihus, hvadan påståendet, att kommissionen vid sitt försök att upphjälpa torpinstitutionen stycks vilja sätta bostaden främst», icke stödes af lagförslaget. Invändningen emot förslaget om ökad ersättningsrätt för verkställda förbättringar gör kommissionen själf i sin motivering, men motiverar ock hvarför den det oaktadt anser förslaget tillrådligt.

Det är möjligt, att de ifrågavarande lagförslagen komma att stanna på den långa väg, de hafva fram till det slutliga afgörandet. Arrendelagstiftningen är alltid ett ömtåligt kapitel. Det är emellertid också möjligt, att förslagen komma att gifva uppslaget till en allmän revision af hela arrendelagen $i$ riktningen af sådana ändringar, som torpkommissionen beträffande torpen förordat, men som den beträffande arrenden $\mathrm{i}$ allmänhet icke varit bemyndigad att taga under ompröfning. Huru emellertid härmed än må gå, torde torpkommissionen hafva tillfredsställelsen att hafva gjort sitt

${ }^{1}$ Sid. 8I i kommissionsbetänkandet.

${ }^{2}$ Sid. 109. 
bästa för att bereda torparbefolkningen de rättsliga förmåner, som kunna anses grundade på rättvisa och billighet. I alla händelser har hr Sommarins invändningar, gjorda hundratals gånger förut och af kommissionen ingående diskuterade, icke $\mathrm{i}$ någon mån bidragit till frågans ytterligare belysande.

Vid sidan af sina lagförslag understryker torpkommissionen betydelsen, äfven för torparklassen, af flera utaf statsmakterna i andra sammanhang upptagna frågor, såsom de mindre jordbrukarnas kreditfråga, landtbruksundervisningsfrågan m. m. Gifvet är att på tal om friköpning af torp äfven egnahemslånefrågan beröres. Kommissionen behandlar spörsmålet, huruvida några ändringar $\mathrm{i}$ gällande egnahemslåneförfattningar ur torparfrågans synpunkt kunna anses önskvärda och kommer efter verkställd utredning till det resultat, att någon särskild apparat för friköpning af torp icke är påkallad, men att vissa mindre ändringar $\mathrm{i}$ egnahemslåneförfattningarna framstå såsom önskvärda. Den föreslår sålunda, att åtgärd vidtages $\mathrm{i}$ ändamål att åvägabringa en likformig tolkning af författningarna i afseende å rätten att belåna bebyggda lägenheter. Utan att framställa några bestämdt formulerade förslag, som icke ansågos lämpliga, emedan en särskild kommission är sysselsatt med revision af egnahemslåneförfattningarna, framhåller kommissionen önskvärdheten från torparfrågans synpunkt däraf, att belånbar lägenhets maximivärde ytterligare höjes, att lån må kunna utlämnas äfven till öfver 50 år gamla torpare, om dessa i öfrigt besitta stadgade kvalifikationer, och att bestämmelser må träffas för att åt torparna bevara företrädesrätt vid torpens friköpning vid sådana egendomsstyckningar, där jordförmedlingsfonden tages $\mathrm{i}$ anspråk. Slutligen underställes den pågående egnahemsutredningens bepröfvande, huruvida vid belåning af bebyggda lägenheter några ytterligare lättnader $\mathrm{i}$ fråga om lånegräns samt ränte- och amorteringsvillkor möjligen skulle kunna medgifvas.

Hr Sommarin, som genom sina föregående reflexioner tydligen anser sig hafva ådagalagt sin praktiska läggning, förklarar om dessa framställningar, att de äro opraktiska förslag, som måste komma att bli resultatlösa. Någon likformig tolkning af ofvan omnämnda art är onödig. Att medgifva lån till öfver 50 år gamla torpare är att s sörja för deras pensionering s, hvilket icke åligger staten. Ett besynnerligt sätt att pensionera, och en så mycket mera intet- 
sägande anmärkning, som meningen ju är att genom en sådan bestämmelse intressera någon torparens son eller måg att i sinom tid öfvertaga torpet och arbeta sig fram till skuldfrihet. Redan den nuvarande författningen tillåter ock $\mathrm{i}$ undantagsfall dispens från åldersgränsen. Ifråga om lånebestämmelsen har recensenten upptäckt ett skriffel å en siffra i kommittétexten samt att kommissionen såsom riksdagsbeslut omnämner vissa bestämmelser, hvilka, medan betänkandet låg $\mathrm{i}$ korrektur, publicerades i svensk författningssamling. De små korrekturläsningsfynden må vara honom unnade. Med häftighet angriper han den af kommissionen endast underställningsvis gjorda framställningen om lättnader ifråga om lånevillkoren vid lån för friköpning af bebyggda lägenheter. Det är naturligtvis möjligt, att inga sådana lättnader anses kunna komma att medgifvas. Herr Sommarins bidrag till frågans belysning utgöres af några mycket riktiga reflexioner om faran af att för starkt forcera egnahemsrörelsen. De hafva emellertid ofta stått att läsa i tidningspressen under de senaste åren och synas, att döma af en not, vara hämtade från häftet 4 af Juhlin-Dannfelts och Sjöströms handbok i jordbruksekonomi.

I stället för torpsakkunniges olika förslag till understödjande af torpens friköpning reflekterar hr S. å ett annat medel: besittningsrätten. För egen del är jag icke motståndare till införandet af en sådan upplåtelsereform vid sidan af äganderätten och underskattar icke de fördelar, den i vissa fall kan erbjuda. Torpkommissionen diskuterade också denna fråga under flera veckor. Hur litet hr S. tänkt sig in $\mathrm{i}$ ämnet framgår emellertid af hans anmärkningar härom. Då frågan är om frigörande af torp å enskilda ägor, hvarom torpkommissionens betänkande rör sig, är besittningsrättens tillämpning, därest icke $\mathrm{i}$ strid med kommissionens och dess kritikers mening en tvångsaflösningslagstiftning ifrågasättes, beroende af jordägarens medgifvande. Underkastar man denna fråga en närmare undersökning, framgår otvifvelaktigt, att ett institut af besittningsrätt skulle vara utan praktisk betydelse vid aflösningar af torp å enskild jord. Af detta skäl finnes i betänkandet intet nämndt om besittningsrätten. Endast å kronojorden kan denna upplåtelsereform få nämnvärd betydelse, men frågan om kronotorpen har torpkommissionen ju icke upptagit i sitt betänkande, af skäl som förut äro omnämnda. Recensentens pole- 
miska reflexioner i detta afseende sväfva fördenskull i luften. På samma sätt förhåller det sig med några andra ställen, där kommissionen förebrås att icke hafva påpekat utvägen för statsmakterna att genom en förändrad skatte- och tullpolitik inverka på torpens marknadsvärden. Utan att ingå på detta ämne - spannmålstullarnas borttagande skulle $\mathrm{f}$. ö. sannolikt stegra priserna å mindre lägenheter - må det vara nog att påpeka, att det uppenbarligen föll utom ramen för de torpsakkunniges uppdrag att inlåta sig på nämnda stora spörsmål.

Jag kunde härmed sluta mitt genmäle, men kan, då jag ändock nödgats läsa sextio sidor af $\mathrm{hr}$ S:s reflexioner, icke neka mig nöjet att kasta en blick på de båda sista sidorna, där han formulerar sitt eget sprogram» till upphjälpande af torparklassen.

Detta "program " omnämner punkterna om ordnande af kreditväsendet för det mindre jordbruket, bostadsinspektion på landsbygden samt landtbruksundervisning för torpare, alla tre frågorna berörda i kommissionens betänkande. ${ }^{1}$ I stället för allt hvad torpkommissionen eljest föreslår, hvilket förkastas, sätter docenten Sommarin följande två punkter, hvilka synas böra anföras i sin ordalydelse:

„förbättrande af torparens rättsliga ställning genom att stärka honom såsom kontrahent vid aftalet med jordägaren, hufvudsakligen genom penningearrendenas genomgående användande i stället för fria dagsverken och torpareföreningar; garanti om fleråriga arrenden';

sdagsverkstorpsystemets betydelse som arbetssystem för det större jordbruket, för hvilket det är oekonomiskt, antages minskas; öfvergång till ökad användning af andra arbetargrupper, särskildt daglönare och ackordsarbetare samt daglönetorpare, till hvilka torpen fortfarande komma att ge tillskott .

Må man studera detta reformprogram. Af första punkten förstår jag intet mera än förslaget, att lagstiftningen skall stadga en längre minimitid för torparrenden än den nu gällande, ett förslag som torpkommissionen ingående behandlar och finner sig böra, icke minst från torparklassens synpunkt, afstyrka. ${ }^{2}$ Senare punkten i

1 Sid. 82, 105, 83-87.

2 Sid. $79-80$. 
reformprogrammet, att dagsverkssystemets betydelse "antages minskas», är ett synnerligen frukbart och positivt program. Hvad där i öfrigt står om önskvärdheten af en öfvergång till stattorp eller daglönartorp är utförligt berördt $i$ torpkommissionens betänkande.

Så slutar det långa inlägget $\mathrm{i}$ torparfrågan med upplysningen, att en förbättring af jordbruksarbetarnas ställning är ett hjälpmedel mot skadlig arbetsbrist vid jordbruket. Man kunde tycka att författaren af sig själf kunde göra denna reflexion. Nej, den omnämnes vara hämtad från sidan 398 i handboken af Juhlin-Dannfelt och Sjöström.

Man kan visserligen $\mathrm{i}$ viss mån förstå, att hr S. känt sig besviken vid studiet af torpkommissionens betänkande. Han är synbarligen sysselsatt med någon jordbruksutredning för Skånes vidkommande, har uppmärksamt läst det lilla fåtal skrifter, som finnas på vårt språk om torparförhållandena, och hade nu väntat sig en större lärobok med historik från medeltiden, utredning af allehanda begrepp $\mathrm{m}$. $\mathrm{m}$. Jag har påpekat, att torpkommissionen, som haft att fasthålla de stora hufvudsynpunkterna och afgifva förslag emot torparklassens tillbakagång, hvarken har varit i tillfälle eller haft rätt att gräfva ned sig i sådana undersökningar. Den har icke heller, äfven om till landtarbetsgifvarföreningarnas utlåtanden fogats något enligt den representativa metoden anskaffadt material, ingått på detaljerade analyser af driftsförhållandena vid olika jordbruk, emedan sådana analyser icke påkallats af motiveringen till de afgifna förslagen. Betydelsen af sådana undersökningar öfver driftsekonomien, baserade på monografier öfver olika gårdar, är naturligtvis icke därmed förnekad, utan jag väntar mig tvärtom intressanta resultat såväl af kommerskollegii pågående undersökningar af denna art, som äfven af doc. Sommarins kommande undersökningar.

Herr Sommarins artikel gifver å andra sidan vid handen, att han, trots den korrekturläsning han underkastat torpsakkunniges betänkande och de understundom om ett slags akademiskt opponentväsende på afvägar vittnande anmärkningar han gör mot framställningen i betänkandet, dock tagit en bristfällig kännedom 
om detta. Jag vill icke yttra mig, huruvida han tagit bättre kännedom om själfva torparfrågan, men påpekar att ett litet förråd af populära handböcker och statistiska uppgifter från Skåne därvid icke hjälper långt.

Stockholm den 13 oktober I9II. 